\title{
Biochemical characterization and synergism of cellulolytic enzyme system from Chaetomium globosum on rice straw saccharification
}

Wanwitoo Wanmolee ${ }^{1}$, Warasirin Sornlake², Nakul Rattanaphan ${ }^{3}$, Surisa Suwannarangsee ${ }^{2}$, Navadol Laosiripojana ${ }^{1,4}$ and Verawat Champreda ${ }^{2,4^{*}}$

\begin{abstract}
Background: Efficient hydrolysis of lignocellulosic materials to sugars for conversion to biofuels and chemicals is a key step in biorefinery. Designing an active saccharifying enzyme system with synergy among their components is considered a promising approach.

Results: In this study, a lignocellulose-degrading enzyme system of Chaetomium globosum BCC5776 (CG-Cel) was characterized for its activity and proteomic profiles, and synergism with accessory enzymes. The highest cellulase productivity of $0.40 \mathrm{FPU} / \mathrm{mL}$ was found for CG-Cel under the optimized submerged fermentation conditions on $1 \%$ (w/v) EPFB (empty palm fruit bunch), $2 \%$ microcrystalline cellulose (Avicel ${ }^{\oplus}$ ) and $1 \%$ soybean meal (SBM) at $30^{\circ} \mathrm{C}$, pH 5.8 for 6 d. CG-Cel worked optimally at $50-60{ }^{\circ} \mathrm{C}$ in an acidic pH range. Proteomics analysis by LC/MS/MS revealed a complex enzyme system composed of core cellulases and accessory hydrolytic/non-hydrolytic enzymes attacking plant biopolymers. A synergistic enzyme system comprising the CG-Cel, a $\beta$-glucosidase (Novozyme ${ }^{\oplus}$ 188) and a hemicellulase Accellerase ${ }^{\circledast} \mathrm{XY}$ was optimized on saccharification of alkaline-pretreated rice straw by a mixture design approach. Applying a full cubic model, the optimal ratio of ternary enzyme mixture containing CG-Cel: Novozyme ${ }^{\circledast}$ 188: Accellerase ${ }^{\oplus}$ XY of 44.4:20.6:35.0 showed synergistic enhancement on reducing sugar yield with a glucose releasing efficiency of $256.4 \mathrm{mg} / \mathrm{FPU}$, equivalent to a 2.9 times compared with that from CG-Cel alone.
\end{abstract}

Conclusions: The work showed an approach for developing an active synergistic enzyme system based on the newly characterized C. globosum for lignocellulose saccharification and modification in bio-industries.

Keywords: Cellulase, Chaetomium globosum, Lignocellulose, Saccharification, Synergistic action

\section{Background}

The shift from petroleum-based industry to a greener bio-based platform is expedited by an increasing concern of global warming. Lignocellulosic plant biomass has attracted attention as a renewable resource for production of biofuels and commodity chemicals in biorefinery.

\footnotetext{
* Correspondence: verawat@biotec.or.th

${ }^{2}$ Enzyme Technology Laboratory, National Center for Genetic Engineering and Biotechnology (BIOTEC), 113 Thailand Science Park, Phahonyothin Road, Khlong Luang, Pathumthani 12120, Thailand

${ }^{4}$ BIOTEC-JGSEE Integrative Biorefinery Laboratory, Innovation Cluster 2 Building, 113 Thailand Science Park, Phahonyothin Road, Khlong Luang, Pathumthani 12120, Thailand

Full list of author information is available at the end of the article
}

Lignocellulosic materials consist mainly of three different types of biopolymers: (i) cellulose, a linear homopolymer of D-glucose organized into highly crystalline microfibers which are intimately associated with an intricate network of (ii) hemicellulose, an amorphous branched polymer comprising various pentoses, hexoses, and sugar acids, and (iii) lignin, a heteropolymer of phenolic alcohols which shields the polysaccharide microstructure from external physical, chemical, and biological attacks. These biopolymers are organized into a complex and highly recalcitrant lignocellulosic structure [1].

In nature, lignocelluloses are degraded by the cooperation of various microorganisms, capable of producing 
an array of cellulolytic, hemicellulolytic, and ligninoloytic enzymes [2, 3]. Cellulases and hemicellulases are mainly composed of various hydrolytic enzymes in different glycosyl hydrolase $(\mathrm{GH})$ families acting synergistically. Cellulases comprise three major groups of enzymes: (1) endoglucanases (EC 3.2.1.4), which attack regions of low crystallinity in cellulose fibers, creating free chain-ends; (2) exo-glucanases or cellobiohydrolases (EC 3.2.1.91) which further degrade the molecule by cleaving cellobiose from the free-chain ends; and (3) $\beta$-glucosidases (EC 3.2.1.21) which hydrolyze cellobiose to produce glucose [4]. In addition to the three major groups of cellulases, there are a number of endo- and exo-acting enzymes that attack the heterogeneous hemicelluloses, such as endo- $\beta$ 1,4-xylanase, $\beta$-xylosidase, galactomannanase, glucomannanase, and acetylesterase. A challenge for development of a feasible biomass industry is identifying efficient lignocellulolytic microbes and developing an active enzyme system based on synergism of the major glycosyl hydrolases and the non-hydrolytic auxiliary components (e.g. expansins and lytic polysaccharide monooxygenases) $[5,6]$. These molecular systems are required for efficient hydrolysis of lignocelluloses to sugars, the key intermediates for subsequent conversion to biorefinery products.

Aerobic fungi belonging to phylum Ascomycota are important plant biomass degraders capable of secreting an array of glycosyl hydrolases and non-hydrolytic auxiliary components. Several ascomycetes are commonly used for producing cellulases and hemicellulases in industry, e.g. Trichoderma, Aspergillus, and Talaromyces [7]. Enzymes from these fungi are different in their composite activities and enzyme components, which have different catalytic characteristics on lignocellulose decomposition. Chaetomium is a saprophytic fungus belonging to Ascomycota with high capability on degrading plant materials [8]. Most studies on Chaetomium, particularly on C. globosum have focused on laccases [9-11] while there have been few studies on their cellulolytic enzyme systems [12]. In this study, a biomass degrading enzyme system of the soft-rot fungus C. globosum BCC5776 was studied. The crude enzyme was characterized for its catalytic activities and its components identified by proteomics. The crude enzyme was used for formulation of an efficient biomassdegrading enzyme mixture by a mixture design approach and applied for hydrolysis of alkaline-pretreated rice straw. The work provides an alternative lignocellulose-degrading enzyme system potent for on-site enzyme production for the development of a feasible biorefinery industry.

\section{Methods}

\section{Strain and media}

Rice straw was obtained from a paddy field in Pathumthani province, Thailand according to the required national guideline. It was physically processed by a cutting mill
(Retsch SM 200, Hann, Germany) and then sieved to particles smaller than $0.5 \mathrm{~mm}$. The biomass was delignified with $10 \%(\mathrm{w} / \mathrm{v}) \mathrm{NaOH}$ at $80{ }^{\circ} \mathrm{C}$ for $90 \mathrm{~min}$ at the solid/liquid ratio of $1: 3$, washed with water until neutral $\mathrm{pH}$ was obtained, and dried at $60{ }^{\circ} \mathrm{C}$ for overnight before use as the substrate for enzymatic hydrolysis. The alkaline-pretreated rice straw contained $74.3 \%$ cellulose, $13.4 \%$ hemicellulose, $1.36 \%$ lignin and $2.9 \%$ ash according to the standard NREL analysis method [13]. Empty palm fruit bunch (EPFB) was obtained from Kasetsart University, Thailand and physically processed by a chopping machine (Model JL800, Zhengzhou, China) and subsequently on a cutting mill and sieved through a $0.5 \mathrm{~mm}$ mesh. C. globosum BCC5776 was identified and obtained from the BIOTEC Culture Collection, Thailand (www.tbrcnetwork.org) and maintained on potato dextrose agar (PDA). Polysaccharides used as substrates in enzymatic activity analysis were obtained from Sigma-Aldrich. Accellerase ${ }^{\oplus} \mathrm{XY}$ (hemicellulase from Trichoderma reesei) and Novozyme ${ }^{\oplus} 188$ ( $\beta$-glucosidase from Aspergillus niger) were obtained from Dupont (Rochester, NY) and Sigma-Aldrich, respectively.

\section{Optimization of cellulase production conditions}

C. globosum BCC5776 was cultivated by submerged fermentation in 250-mL conical flasks. The inoculum was prepared from the culture grown on PDA by plunging four agar pieces covered with profuse mycelia using a cock borer no. 2 and inoculated into $50 \mathrm{~mL}$ of the production medium $(4 \%(\mathrm{w} / \mathrm{v})$ of microcrystalline cellulose Avicel $^{\odot}$ and $1 \%(\mathrm{w} / \mathrm{v})$ of soybean meal in water). The culture was incubated at $30{ }^{\circ} \mathrm{C}$ for $6 \mathrm{~d}$ with shaking at $200 \mathrm{rpm}$. Culture media and conditions were varied as specified including concentration of Avicel $^{\oplus}(2,4$, and $6 \%$ $(\mathrm{w} / \mathrm{v}))$, concentration of lactose $(0,0.05$, and $0.1 \%(\mathrm{v} / \mathrm{v}))$ and $\mathrm{pH}$ (5.8 and 7.0 using $50 \mathrm{mM}$ potassium phosphate buffer). Effect on addition of $1 \%(\mathrm{w} / \mathrm{v})$ empty palm fruit bunch (EPFB) as a co-carbon source for induction of cellulase was also studied. The cultures were collected periodically for determination of cellulase activity using the dinitrosalicylic acid (DNS) method [14]. The experiments were performed in triplicate and the average of cellulase activity was used as the response (dependent variable). The data were analyzed using SPSS 16.0 (StatSoft, Inc., Tulsa, OK).

\section{Enzyme production and purification}

A $10 \%(\mathrm{v} / \mathrm{v})$ inoculum grown in the optimal production medium containing $2 \%$ Avicel $^{\oplus}$, 1\% EPFB, $1 \%$ soybean meal (SBM), $0.1 \%$ lactose, and initial $\mathrm{pH}$ of 5.8 at $30{ }^{\circ} \mathrm{C}$ for $6 \mathrm{~d}$ was inoculated into a $5 \mathrm{~L}$ bioreactor (BIOSTAT BDCU, Sartorius, Göttingen, Germany) with a 3 L working volume of the same medium. The culture was incubated at $30{ }^{\circ} \mathrm{C}$ for $6 \mathrm{~d}$ with constant mixing at $200 \mathrm{rpm}$ and oxygen feed of $1 \mathrm{vvm}$. The fungal mycelia were separated 
by filtration on gauze and clarified by centrifugation at $10,000 \times \mathrm{g}$ for $10 \mathrm{~min}$. The supernatant was then filtered through a $0.2 \mu \mathrm{m}$ Supor -200 membrane (Pall Corp, Ann Arbor, MI) followed by concentration $(5 \times)$ using a Minimate $^{\mathrm{Tw}}$ tangential flow filtration (TFF) system equipped with a 10-kDa MWCO TFF membrane (Pall Corp, Ann Arbor, MI, USA). The enzyme was kept at $4{ }^{\circ} \mathrm{C}$ and used in subsequent experiments.

\section{Enzyme activity assays}

Polysaccharide-degrading enzyme activities were analyzed using the 3,5-dinitrosalicylic acid (DNS) method by measuring the amount of reducing sugars liberated [14] according to the standard procedure recommended by the Commission on Biotechnology, IUPAC [15] with modifications on the total reaction volume. Reactions of $3.5 \mathrm{~mL}$ contained $100 \mathrm{mM}$ sodium acetate phosphate buffers, $\mathrm{pH} 5.5$ with an appropriate dilution of the enzyme using a $1 \times 6 \mathrm{~cm}$ Whatman no. 1 filter paper as the substrate and incubated at $50{ }^{\circ} \mathrm{C}$ for $60 \mathrm{~min}$ for determining the Filter paper activity (FPase) as filter paper unit (FPU). The carboxymethyl cellulase (CMCase), xylanase, mannanase, amylase, and pectinase activities were assayed using 1\% (w/v) carboxymethyl cellulose, 1\% (w/ v) birchwood xylan, $0.5 \%(\mathrm{w} / \mathrm{v})$ locust bean gum, $1 \%(\mathrm{w} /$ v) soluble starch, and $0.5 \%(\mathrm{w} / \mathrm{v})$ pectin from citrus peels as the substrates, respectively. The reactions were incubated at $50{ }^{\circ} \mathrm{C}$ for $30 \mathrm{~min}$. The amount of reducing sugars was determined at the end of the reaction by measuring the absorbance at $540 \mathrm{~nm}$ using a UV-Vis spectrophotometer microplate reader (Multiskan Ascent, Thermo Scientific, Cambridge, MA) and interpolation from a standard curve prepared using dilutions of the corresponding sugar as standards. One enzyme activity unit $(\mathrm{U})$ is defined as the amount of enzyme required to release $1 \mu \mathrm{mol}$ of reducing sugars from a substrate in 1 min under the assay condition. The $\beta$-glucosidase and $\beta$-xylosidase activities were assayed using $0.1 \%(\mathrm{w} / \mathrm{v}) p$ nitrophenyl- $\beta$-D-glucopyranoside (PNPG) and $p$-nitrophenyl- $\beta$-D-xylopyranoside (PNPX) as the substrates, respectively in $3 \mathrm{~mL}$ reactions containing an appropriate amount of enzyme in $100 \mathrm{mM}$ sodium acetate buffer (pH 5.5). The reactions were incubated at $50{ }^{\circ} \mathrm{C}$ for $30 \mathrm{~min}$ and terminated by the addition of $2 \mathrm{~mL}$ of $1 \mathrm{M}$ $\mathrm{Na}_{2} \mathrm{CO}_{3}$. The quantity of $p$-nitrophenolate was measured spectrophotometrically at $405 \mathrm{~nm}$ at the end of the reaction. One activity unit $(\mathrm{U})$ is defined as amount of enzyme that produces $1 \mu \mathrm{mol} p$-nitrophenolate per minute under the experimental conditions. The total protein concentration of the crude enzyme extracts was determined using Bradford's method with the BioRad's Protein Assay reagent (BioRad, Hercules, CA) using bovine serum albumin (BSA) as the standard. The experiments were performed in triplicate.

\section{Proteomic analysis}

The enzyme preparation was applied to a $10 \%$ SDSPAGE gel and separated using a MiniProtean II cell (Biorad, Hercules, CA, USA). The protein bands were visualized by staining with Coomassie blue R-250 and were manually excised into five fractions according to their apparent molecular weights $(14.4-116.0 \mathrm{kDa})$. The polypeptides in gel were then digested with trypsin (Ettan Spot Handling Workstation User Manual 181153-55 Edition AC, GE Healthcare Biosciences, Uppsala, Sweden). The tryptic peptides were resuspended with $0.1 \%$ formic acid and analyzed on a Finigan LTQ linear ion trap mass spectrometer (Thermo Scientific, San Jose, CA, USA) according to a method described in Wongwilaiwalin et al., [16]. All MS/MS spectra were searched using the Mascot ${ }^{\ominus}$ search engine (Matrix Science, Boston, MA) against the NCBI-nr database following criteria: enzyme trypsin, static modification of Cys $(+57.05130 \mathrm{Da})$, with differential modification of Met $(+15.99940)$. The search results were filtered by cross-correlation versus charge state $(+1 \geq 1.5, \quad+2 \geq$ $2.0,+3 \geq 2.5$ ) and protein probability (minimum $1.00 \mathrm{E}^{-3}$ ). The candidate protein queries were mapped to the UniProt Knowledge base [17].

\section{Synergistic action of C. globosum enzyme to commercial enzymes}

Interactions among the C. globosum enzyme (CG-Cel), Novozyme $^{\circ} 188$ and Accellerase ${ }^{\circ} \mathrm{XY}$ were studied using experimental mixture design approach [18] with a fixed total enzyme volume [19]. The enzymatic hydrolysis reactions of $1 \mathrm{~mL}$ total volume contained $5 \%(\mathrm{w} / \mathrm{v})$ alkaline-pretreated biomass in $100 \mathrm{mM}$ sodium acetate buffer ( $\mathrm{pH}$ 5.5) supplemented with $1 \mathrm{mM}$ sodium azide and incubated at $50{ }^{\circ} \mathrm{C}$ for $48 \mathrm{~h}$ with rotary shaking at $200 \mathrm{rpm}$. An optimal enzyme mixture releasing the highest reducing sugar yield was defined by a $\{3,3\}$-augmented simplex lattice design using Minitab 16.0 software (Minitab Inc., State College, PA). The design contained 13 experimental points (see design summarized in Table 3), which were performed in quadruplicate with three components and a lattice degree of three. The three independent variables in the mixture design consisted of CG-Cel (X1), Novozyme 188 (X2), and Accellerase ${ }^{\circ} \mathrm{XY}$ (X3). The sum of all enzyme components in the reactions were $100 \%$ with the total enzyme volume fixed at $80 \mu \mathrm{L}$. The amount of released reducing sugar (Y1) was used as dependent variables for simulation of the respondent model equation. The amount of reducing sugars liberated at the end of the reactions was determined using the DNS method at the end of the reaction [14]. The sugar profile in the hydrolyzates was analyzed by high performance liquid chromatography (Waters e2695, Waters, Milford, MA) equipped with a differential refractometer using an 
Aminex HPX-87H column (Bio-Rad, Hercules, CA). The column temperature was $65{ }^{\circ} \mathrm{C} . \mathrm{H}_{2} \mathrm{SO}_{4}$ solution $(5 \mathrm{mM})$ was used as the mobile phase at a flow rate of $0.5 \mathrm{~mL} /$ min. Concentration of sugar was determined from the calibration curve of standard solution. The experiments were performed in quadruplicate. Sugars from control reactions containing heat-inactivated enzymes were subtracted from the data.

\section{Mixture design analysis}

After regression analysis, the full cubic model was used to simulate the optimized ratio of the mixture components. The canonical correlation of the full cubic model is shown in Eq. (1):

$$
\begin{aligned}
Y & =\sum_{i=1}^{3} \beta_{i} X_{i}+\sum \sum_{i<j}^{3} \beta_{i j} X_{i} X_{j} \\
& +\sum \sum_{i<j}^{3} \delta_{i j} X_{i} X_{j}\left(X_{i}-X_{j}\right)+\sum \sum \sum_{i<j<k}^{3} \beta_{i j k} X_{i} X_{j} X_{k}
\end{aligned}
$$

where $\mathrm{Y}$ is a predicted response, $\beta_{\mathrm{i}}$ is a linear coefficient, $\beta_{\mathrm{ij}}$ is a quadratic coefficient, and $\beta_{\mathrm{ijk}}$ is a cubic coefficient. $\beta_{\mathrm{ij}}$ is a parameter of the model. $\beta_{\mathrm{i}} \mathrm{X}_{\mathrm{i}}$ represents the linear blending portion, and the parameter $\beta_{\mathrm{ij}}$ represents either synergistic or antagonistic blending.

\section{Results and discussion}

\section{Optimization of enzyme production conditions}

Production of cellulolytic enzyme from C. globosum BCC5776 by submerged fermentation was studied. The optimization study included three variables: (1) concentration of $\mathrm{Avicel}^{\circ}$, (2) concentration of lactose, and (3) initial $\mathrm{pH}$ previously identified to show significant effects $(p<0.05)$ on cellulase level of the fungus in the preliminary screening of factors influencing enzyme production. According to Table 1, the basic fermentation condition containing Avicel $^{\circ}$ as the

Table 1 Effects of variables to cellulase activities in fermentation

\begin{tabular}{|c|c|c|c|c|c|}
\hline \multirow[t]{2}{*}{ No. } & \multicolumn{2}{|c|}{ Concentration (\%) } & \multirow{2}{*}{$\begin{array}{l}\text { Initial } \\
\mathrm{pH}\end{array}$} & \multicolumn{2}{|l|}{ Activity } \\
\hline & Avicel $^{\circledast}$ & Lactose & & CMCase $(\mathrm{U} / \mathrm{mL})$ & FPase $(\mathrm{FPU} / \mathrm{mL})$ \\
\hline 1 & 4 & - & 5.5 & $6.37 \pm 0.01$ & $0.21 \pm 0.03$ \\
\hline 2 & 2 & 0.05 & 5.8 & $7.02 \pm 0.01$ & $0.22 \pm 0.05$ \\
\hline 3 & 2 & 0.1 & 5.8 & $7.19 \pm 0.00$ & $0.32 \pm 0.01$ \\
\hline 4 & 2 & 0.05 & 7.0 & $5.10 \pm 0.03$ & $0.20 \pm 0.00$ \\
\hline 5 & 2 & 0.1 & 7.0 & $5.54 \pm 0.02$ & $0.17 \pm 0.01$ \\
\hline 6 & 6 & 0.05 & 5.8 & $6.87 \pm 0.04$ & $0.18 \pm 0.00$ \\
\hline 7 & 6 & 0.1 & 5.8 & $6.68 \pm 0.01$ & $0.20 \pm 0.01$ \\
\hline 8 & 6 & 0.05 & 7.0 & $6.12 \pm 0.05$ & $0.17 \pm 0.00$ \\
\hline 9 & 6 & 0.1 & 7.0 & $5.07 \pm 0.04$ & $0.17 \pm 0.03$ \\
\hline
\end{tabular}
of BCC5776 sole carbon source (run no. 1) resulted in the CMCase and FPase activity of 6.37 and $0.21 \mathrm{U} / \mathrm{mL}$, respectively. Further increases in Avicel $^{\circ}$ (run no. 69) did not enhance the target enzymatic activities. Addition of lactose (run no. 2-9) was found to significantly $(p<0.05)$ induce cellulase production level when compared with the same conditions in the absence of lactose. Higher cellulase productivity was found at acidic $\mathrm{pH}$ (5.8) compared with that observed under neutral conditions. The highest CMCase and FPase activities of $7.19 \mathrm{U} / \mathrm{mL}$ and $0.32 \mathrm{FPU} / \mathrm{mL}$, respectively, were recorded after $144 \mathrm{~h}$ of fermentation in run no. 3 containing $1 \%$ lactose and an inducer with controlled $\mathrm{pH}$ at 5.8. This up-regulation of cellulase by lactose was previously reported in C. papyrosolvens [20] and A. cellulolyticus [21] where lactose was shown to act as an effective inducer of cellulase biosynthesis, which is controlled by a regulator protein responsive to the concentration of the target substrate [22]. The preference for acidic $\mathrm{pH}$ for production of cellulase and other lignocellulose degrading enzymes has been reported for most cellulase producing ascomycetes fungi e.g. T. reesei [23], A. cellulolyticus [24], and C. globosum [25]. This preference is related to $\mathrm{pH}$ for optimal growth and catalytic activity of the enzymes.

Addition of EPFB as a co-substrate at $1 \%(\mathrm{w} / \mathrm{v})$ concentration under submerged fermentation was found to further improve the cellulase production by C. globosum BCC5776. This led to the enhancement of endo-glucanase (CMCase) and total cellulase (FPase) activities to $10.57 \mathrm{U} / \mathrm{mL}$ and $0.40 \mathrm{FPU} / \mathrm{mL}$, equivalent to 47 and $25 \%$ increases, respectively, compared with those obtained in its absence (Fig. 1a and $b$ ). The use of agro-industrial wastes as the sole carbon source or in combination with pure cellulose as an effective and cost-efficient substrate for production of plant biomass degrading enzymes e.g. cellulase, hemicellulase, and pectinase production has been demonstrated in many fungal strains [26-28]. The cellulase activities produced by C. globosum in this study were in the same range (or higher in some cases, particularly for the CMCase activity) compared to several wild type fungi in genera Aspergillus, Acremonium, Trichodema, and Schizophyllum reported in many recent publications, which were in the range of 0.01-1.33 FPU/mL. The very high cellulase activities (up to five $\mathrm{FPU} / \mathrm{ml}$ ) were achieved by mutants or genetically modified fungal strains. Comparison of cellulase activities produced by different fungal strains recently reported is shown in the Additional file 1: Table S1.

The optimized enzyme production medium (2\% Avicel $^{\circ}, 1 \%$ EPFB, $0.1 \%$ lactose, and $1 \%$ soybean meal at 

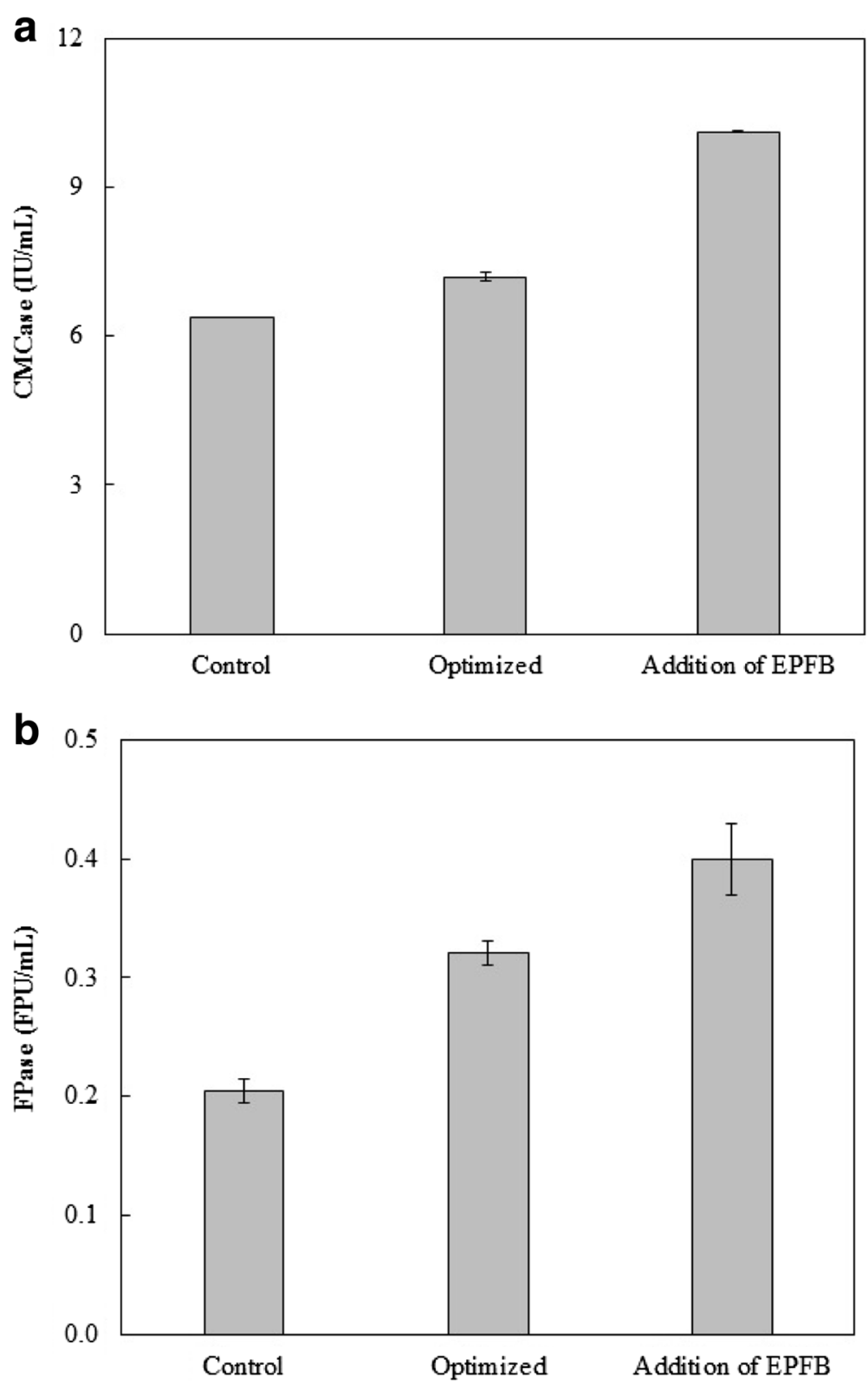

Fig. 1 Comparison of (a) CMCase and (b) FPase activities from C. globosum BCC5776 under various conditions. The cultures were incubated at 30 ${ }^{\circ} \mathrm{C}$ for $144 \mathrm{~h}$ with continuous shaking at $200 \mathrm{rpm}$. Control medium (4\% (W/v) of microcrystalline cellulose Avicel ${ }^{\oplus}$ and $1 \%(\mathrm{~W} / \mathrm{V})$ of soybean meal in water); Optimized medium (2\% (W/v) microcrystalline cellulose Avicel ${ }^{\oplus}, 0.1 \%(\mathrm{~V} / \mathrm{v})$ lactose, and $1 \%(\mathrm{~W} / \mathrm{v})$ soybean meal with $50 \mathrm{mM}$ potassium phosphate, pH 5.8); Optimized medium + 1\% (w/v) EPFB

$\mathrm{pH}$ 5.8) was used for production of the crude enzyme (CG-Cel) in a laboratory-scale fermenter. The enzyme showed similar composite activities to those obtained in the small scale experiments. The crude enzyme preparation (Table 2) contained a relatively high level of endo-glucanase as shown by CMCase activity $(15.7 \mathrm{U} / \mathrm{mL})$ with FPase activity $(0.4 \mathrm{FPU} / \mathrm{mL})$. Strong endo- $\beta-1,4$-xylanase $(28.2 \mathrm{U} / \mathrm{mL})$ and endo- $\beta$ 1,4-mannanase $(13.6 \mathrm{U} / \mathrm{mL})$ activities were found together with other enzymes involved in plant polysaccharide degradation, such as pectinase $(0.8 \mathrm{U} / \mathrm{mL})$ and amylase $(0.5 \mathrm{U} / \mathrm{mL})$. However, regardless of the high activities of endo-acting glycosyl hydrolases, the crude enzyme exhibited substantially weak downstream activities i.e. $\beta$-glucosidase $(1.5 \mathrm{U} / \mathrm{mL})$ and $\beta$ xylosidase $(0.04 \mathrm{U} / \mathrm{mL})$ activities, which could limit degradation of cellulose and hemicelluloses to sugars. The $5 \times$ concentrated enzyme contained the cellulase 
Table 2 The composite enzyme activity profiles of C. globosum BCC5776 enzyme extracts

\begin{tabular}{lc}
\hline Enzyme & Activity $(\mathrm{U} / \mathrm{mL})^{\mathrm{a}}$ \\
\hline CMCase & 15.70 \\
FPase & 0.40 \\
$\beta$-glucosidase & 1.50 \\
Xylanase & 28.20 \\
$\beta$-xylosidase & 0.04 \\
Amylase & 0.50 \\
Mannanase & 13.60 \\
Pectinase & 0.80
\end{tabular}

${ }^{\text {a Protein concentration }}=1.30 \mathrm{mg} / \mathrm{mL}$

activity of $2.0 \mathrm{FPU} / \mathrm{mL}$ while $>90 \%$ activities of other enzymes were retained.

\section{Synergistic action of CG-Cel and commercial enzymes}

The mixture design approach was applied to study synergistic and cooperative interactions among CGCel and a hemicellulase, Accellerase ${ }^{\circ} \mathrm{XY}$, and a $\beta$ glucosidase, Novozyme ${ }^{\circledR} 188$, chosen from our prescreening study on identification of additive enzymes with complementing activities to the core cellulase (see the comparative enzyme profiles in Fig. 2). The measured response of this method was presumed to depend only on the enzyme proportion of the complements in the mixture. A $\{3,3\}$-simplex lattice model was applied which comprised 13 experimental points located inside the triangular graph, in which the sum of the three component loading for every experimental point was always $100 \%$ based on a volumetric basis. According to this design, the cellulase dosages as FPU loading/g substrate of each experimental point was varied according to different proportions of CG-Cel: Novozyme ${ }^{\oplus} 188$ : Accellerase ${ }^{\circledR} \mathrm{XY}$. Each point was operated in quadruplicate to minimize the effect of experimental error.

The reducing sugar yield obtained from each experimental condition in the mixture design is summarized in Table 3 . The standard deviation of all the data points was $\leq 5 \%$ of the mean. CG-Cel, equivalent to the FPase activity of $3.2 \mathrm{FPU} / \mathrm{g}$ (No. 1), demonstrated a higher reducing sugar yield (500.9 mg/g) than those obtained with the $\beta$-glucosidase Novozyme ${ }^{\circledR} 188$ (No. 7) and the hemicellulase Accellera$\mathrm{se}^{\oplus} \mathrm{XY}$ (No. 10) alone. The binary combinations between CG-Cel and Accellerase ${ }^{\oplus} \mathrm{XY}$ (No. 3 and 6) led to slight increases in reducing sugar yields (519.3-525.4 mg/g) compared with that of CG-Cel alone, despite the lower total FPase dosage in the reaction (1.17-2.18 FPU/g). Ternary mixtures of all three enzymes at specific compositions resulted in

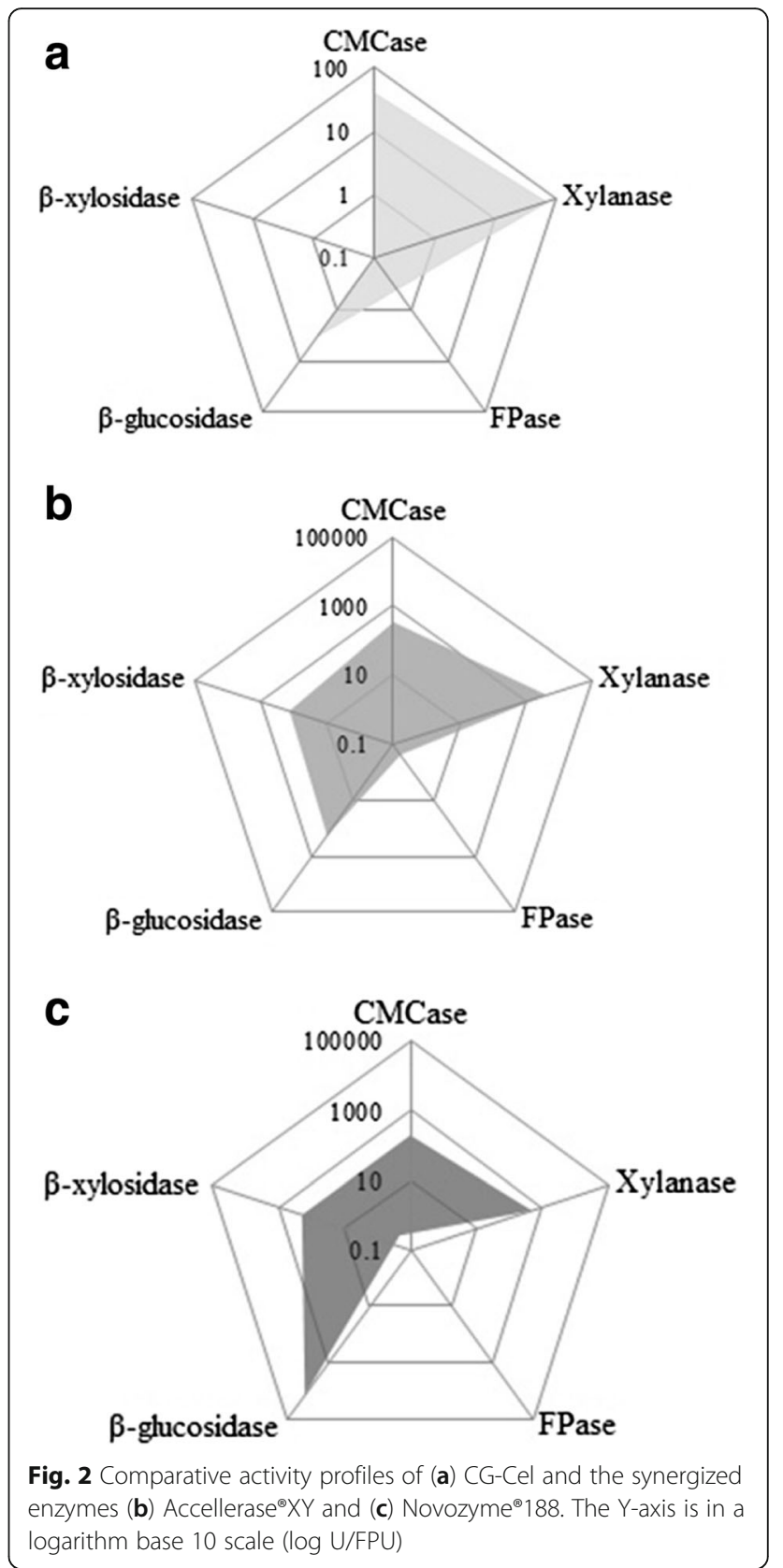

further increases in the total reducing sugar yields, with the maximal reducing sugar yield of $567.8 \mathrm{mg} / \mathrm{g}$ (No. 11) which contained a 4:1:1 ratio of BCC5776: Novozyme ${ }^{\circledast}$ 188: Accellerase ${ }^{\oplus} \mathrm{XY}$, suggesting synergism of the three enzymes.

The response data for the reducing sugar were then analyzed using multiple regression analysis from the linear to full cubic model. The full cubic model was found to be the best fitted model for the reducing sugar $\left(\mathrm{R}^{2}=97.30 \%, \mathrm{P}_{\text {Model }}<0.01\right)$. The ANOVA analysis of the full cubic model is illustrated in 
Table 3 Design of experiment for enzymatic hydrolysis of pretreated rice straw and the associated response data

\begin{tabular}{|c|c|c|c|c|c|}
\hline \multirow[t]{3}{*}{ Run no. } & \multirow{2}{*}{\multicolumn{3}{|c|}{$\%$ composition }} & \multirow{2}{*}{\multicolumn{2}{|c|}{$\frac{\text { Reducing sugar }}{\text { ( } \mathrm{mg} / \mathrm{g} \text { biomass) }}$}} \\
\hline & & & & & \\
\hline & BCC5776 & Novozyme $^{\oplus 188}$ & Accellerase ${ }^{\circledast} X Y$ & Average & SD \\
\hline 1 & 100.0 & 0.0 & 0.0 & 500.9 & 2.6 \\
\hline 2 & 66.7 & 33.3 & 0.0 & 493.1 & 2.2 \\
\hline 3 & 66.7 & 0.0 & 33.3 & 525.4 & 0.5 \\
\hline 4 & 33.3 & 66.7 & 0.0 & 421.2 & 4.3 \\
\hline 5 & 33.3 & 33.3 & 33.3 & 535.6 & 2.6 \\
\hline 6 & 33.3 & 0.0 & 66.7 & 519.3 & 3.2 \\
\hline 7 & 0.0 & 100.0 & 0.0 & 69.2 & 3.4 \\
\hline 8 & 0.0 & 66.7 & 33.3 & 205.3 & 4.1 \\
\hline 9 & 0.0 & 33.3 & 66.7 & 233.3 & 4.6 \\
\hline 10 & 0.0 & 0.0 & 100.0 & 205.0 & 4.9 \\
\hline 11 & 66.7 & 16.7 & 16.7 & 567.8 & 1.7 \\
\hline 12 & 16.7 & 66.7 & 16.7 & 426.1 & 1.4 \\
\hline 13 & 16.7 & 16.7 & 66.7 & 483.5 & 2.1 \\
\hline
\end{tabular}

Reactions $(1 \mathrm{~mL})$ contained $5 \%(\mathrm{w} / \mathrm{v})$ alkaline-pretreated rice straw in $100 \mathrm{mM}$ sodium acetate buffer, $\mathrm{pH} 5.5$ with a total enzyme volume of $80 \mu \mathrm{L}$ and incubated at $50{ }^{\circ} \mathrm{C}$ for $48 \mathrm{~h}$

Table 4. For a single factor, CG-Cel, Novozyme ${ }^{\circ} 188$, Accellerase ${ }^{\circ} \mathrm{XY}$ coefficients showed a positive correlation with the reducing sugar yield. Marked synergisms between CG-Cel and Novozyme ${ }^{\circ} 188$ or Accellerase $^{\circ} \mathrm{XY}$ were observed (786.6 and 845.1), with a weak synergistic interaction between Novozyme ${ }^{\circ} 188$ and Accellerase ${ }^{\circ} \mathrm{XY}$. The highest coefficient was observed for the CG-Cel ${ }^{*}$ Novozyme ${ }^{\circ} 188^{*}$ Accellerase ${ }^{\circ} \mathrm{XY}$, indicating strong interactions among these components. The fitted equation for the reducing sugar yield based on the significant terms is shown in Eq. (2):

$$
\begin{aligned}
\text { Reducing sugar }(\mathrm{mg} / \mathrm{g})= & 4.82685 * \text { BCC5776 } \\
+ & 0.72036 * \text { Novozyme } 188 \\
+ & 2.04999 * \text { AccelleraseXY } \\
+ & 0.07866 * \text { BCC } 5776 * \text { Novozyme } 188 \\
+ & 0.08451 * \text { BCC5776 } * \text { AccelleraseXY } \\
+ & 0.03772 * \text { Novozyme } 188 * \text { AccelleraseXY } \\
+ & 0.00253 * \text { BCC } 5776 * \text { Novozyme } 188 \\
& * \text { AccelleraseXY }(-)-0.00059 * \text { BCC5776 } \\
& * \text { Novozyme } 188(-)-0.00053 * \text { BCC5776 } \\
& * \text { AccelleraseXY }(-)
\end{aligned}
$$

The responses of reducing sugar yield with respect to component combinations are represented by a ternary mixture contour plot (Fig. 3). The area that emphasized the greatest reducing sugar was in the middle of the CG-Cel and Accellerase ${ }^{\circ} \mathrm{XY}$ axes, and near the bottom of the Novozyme 188 vertex. This implies that a high level of reducing sugars could be achieved when CG-Cel was the major component with Novozyme 188 and Accellerase ${ }^{\circ} \mathrm{XY}$ in the minority. The optimal enzyme combination based on the maximal reducing sugar yield was determined to be $44.4 \%$ CG-Cel, $20.6 \%$ Novozyme $^{\circ} 188$, and $35.0 \%$ Accellerase ${ }^{\circ} \mathrm{XY}$ with a predicted reducing sugar yield of $591.2 \mathrm{mg} / \mathrm{g}$ pretreated rice straw with the total cellulase activity of $1.49 \mathrm{FPU} / \mathrm{g}$. An experimental reducing experimental sugar yield of $572.7 \mathrm{mg} / \mathrm{g}$ was obtained, validating the model. The ternary enzyme mixture was found to increase the yields of all major composite sugars (i.e. glucose, xylose, and arabinose)

\begin{tabular}{|c|c|c|c|c|}
\hline Factor & Coefficient & SE & $\mathrm{T}$ & $p$-value \\
\hline BCC5776 & 482.7 & 14.3 & * & * \\
\hline Novozyme188 & 72 & 14.3 & * & * \\
\hline AccelleraseXY & 205 & 14.3 & * & * \\
\hline BCC5776*Novozyme188 & 786.6 & 63.94 & 12.3 & 0.000 \\
\hline BCC5776*AccelleraseXY & 845.1 & 63.94 & 13.22 & 0.000 \\
\hline Novozyme188*AccelleraseXY & 377.3 & 63.94 & 5.9 & 0.000 \\
\hline BCC5776*Novozyme188*Accellerase XY & 2534.8 & 416.85 & 6.08 & 0.000 \\
\hline BCC5776*Novozyme188*(-) & -586.8 & 122.48 & -4.79 & 0.000 \\
\hline BCC5776*AccelleraseXY*(-) & -528.2 & 122.48 & -4.31 & 0.000 \\
\hline Novozyme188*AccelleraseXY*(-) & 78.8 & 122.48 & 0.64 & 0.523 \\
\hline$S=28.6660$ & \multicolumn{4}{|c|}{ PRESS $=47389.9$} \\
\hline$R^{2}=97.30 \%$ & \multicolumn{2}{|c|}{$R^{2}($ pred $)=96.29 \%$} & \multicolumn{2}{|c|}{$R^{2}(\operatorname{adj})=96.72 \%$} \\
\hline
\end{tabular}
from hydrolysis of the pretreated rice straw. The glucose yield (Additional file 2: Table S2) obtained using the optimal enzyme mixture was $381.2 \mathrm{mg} / \mathrm{g}$, which was higher than that obtained using the individual enzymes (Fig. 4a). This led to the increase in glucose releasing efficiency from $88.7 \mathrm{mg}$ glucose/FPU from CG-Cel alone by 2.9 fold to $256.4 \mathrm{mg}$ glucose/FPU of the ternary optimal enzyme mixture. ( $p<0.05$ by $T$-test) [29]. Further increases in the

Table 4 The regression model analysis of the $\{3,3\}$ full cubic model 


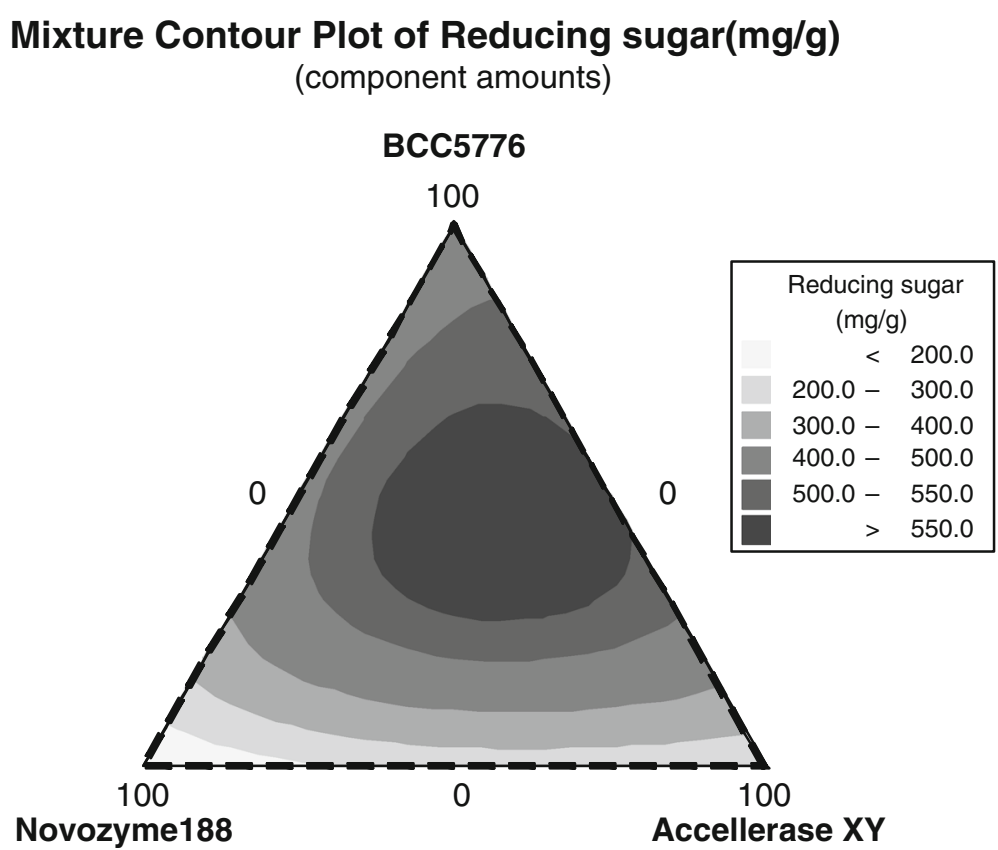

Fig. 3 The contour plot of the experimental design optimization of the ternary enzyme complex. One hundred percent component amount is equal to $80 \mu \mathrm{L}$ total reaction volume

total enzyme loading from $1 \times(1.49 \mathrm{FPU} / \mathrm{g})$ to $4 \times(5.96$ $\mathrm{FPU} / \mathrm{g}$ ) led to a stepwise increase in reducing sugar yield to $764.7 \mathrm{mg} / \mathrm{g}$ and glucose released to $474.8 \mathrm{mg} / \mathrm{g}$; however, respective decreases in glucose releasing efficiency were observed at higher enzyme loadings (Fig. 4b).

\section{Proteomic analysis of BCC5776 crude enzyme}

In order to analyze the composite glycosyl hydrolases and accessory non-hydrolytic enzymes with functions on attacking lignocellulosic materials in CG-Cel, the composite proteins in the secretome of BCC5776 (see Additional file 3: Figure S1) was analyzed using LC/MS/MS. Twenty seven different proteins were identified in CG-Cel, from which $81 \%$ were annotated as functional proteins while the rest were classified as hypothetical proteins. The majority of them are hydrolytic enzymes attacking cellulose and hemicelluloses, with a substantial fraction of non-cellulosic polysaccharide hydrolyzing enzymes (Table 5). Most of them are closely related to homologous enzymes in Neofusicoccum parvum UCRNP2 and other ascomycetes. The cellulose degrading enzymes were classified into various glycosyl hydrolase families and nonhydrolytic enzymes in different classes. The cellulolytic components are annotated as 5 endo-glucanases (GH5 and 7) and 8 cellobiohydrolases, including CBH-I (GH6 and 7), which attacks the reducing end of cellulose chain, and $\mathrm{CBH}-\mathrm{II}$, which attacks the non-reducing end, releasing cellobiose units, in addition to one carbohydrate binding module (CBM1).
A few hemicellulolytic enzymes were also identified in the BCC5776 secretome. These included GH10 and 11 endo- $\beta$-1,4-xylanase, a key endo-acting hemicellulase attacking xylan, the major component in hemicellulose in addition to exo-acting enzymes including a $\beta$ galactosidase (GH35) and $\alpha$-mannosidase (GH47). Nonhydrolytic counterparts included a cellobiose dehydrogenase acting on oxidizing cellodextrins, an intermediate in cellulose hydrolysis to their corresponding lactones, and a polysaccharide deacetylase functioning on acetyl group branches in hemicelluloses. The functions of both enzymes on synergistic and cooperative actions with core cellulases have been demonstrated [30]. Other hydrolases in the secretome are mainly related to different classes of proteases, e.g. carboxypeptidase s1, leucyl aminopeptidase, and tripeptidyl-peptidase 1 . No other non-cellulosic polysaccharide degrading enzymes e.g. amylases or pectinases were identified. The proteomic profiles of the secretome thus point to a lack of downstream cellulose degrading enzyme (i.e. a $\beta$-glucosidase) and various hemicellulolytic components. The lack of these activities could explain why CG-Cel is strongly synergistic with supplemented pure $\beta$-glucosidase and hemicellulases.

Synergism of core cellulases with hemicellulases and auxiliary components in various classes of carbohydrate processing enzymes according to the Carbohydrate Active Enzymes Database (CaZY) [31] has been demonstrated and could be applied for developing efficient enzyme systems for bioindustries. Their synergistic 

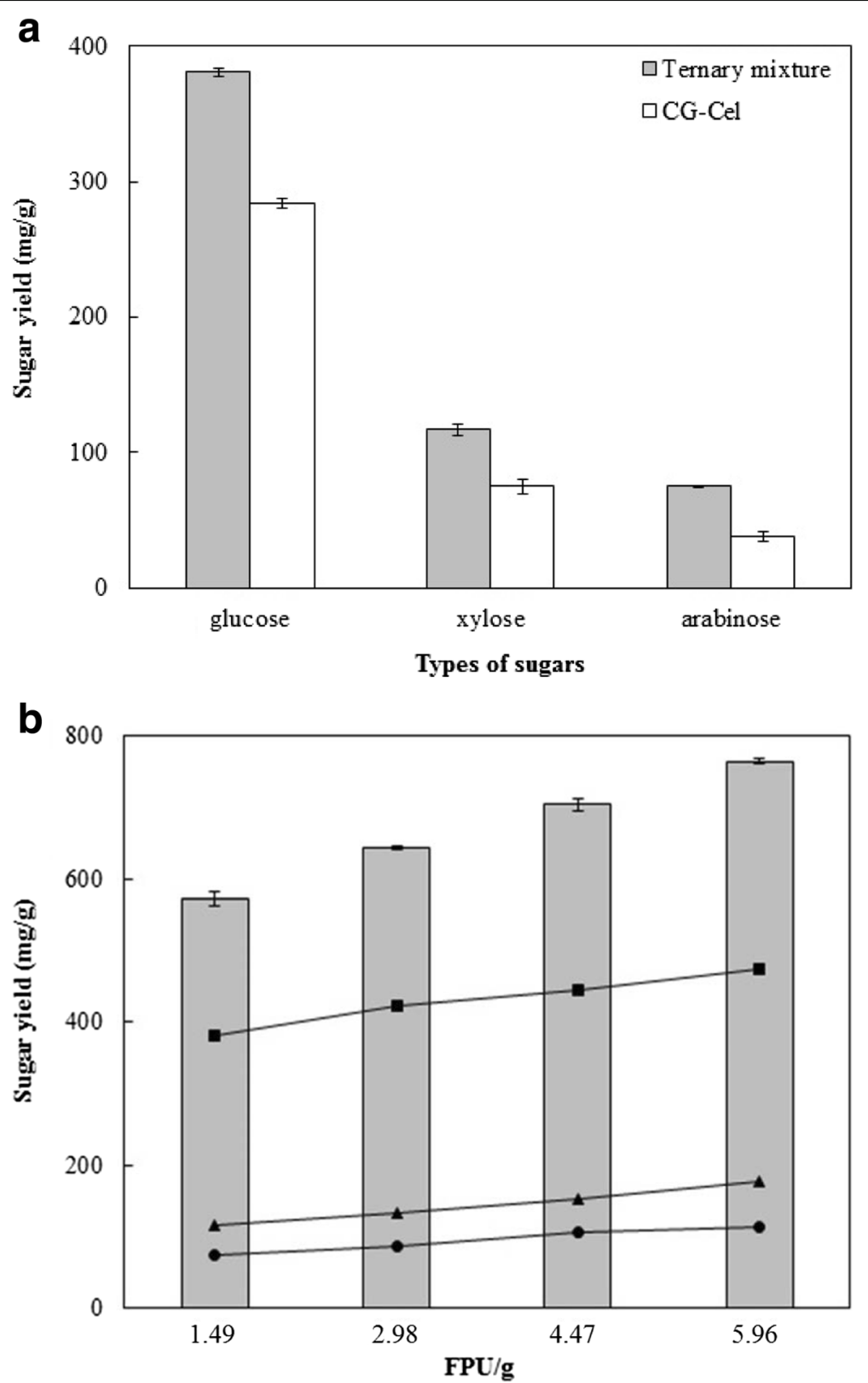

Fig. 4 Saccharification of pretreated rice straw using the optimal enzyme mixture compared with individual enzymes. The reactions (1 $\mathrm{mL})$ contained 5\% (w/v) alkaline-pretreated rice straw in $100 \mathrm{mM}$ sodium acetate buffer, $\mathrm{pH} 5.5$ with a fixed total enzyme volume of $80 \mu \mathrm{L}(1 \times)$ and incubated at $50{ }^{\circ} \mathrm{C}$ for $48 \mathrm{~h}$. (a) sugar profile of optimal enzyme mixture; (b) the total reducing sugars (bar) and individual sugar profile ((-

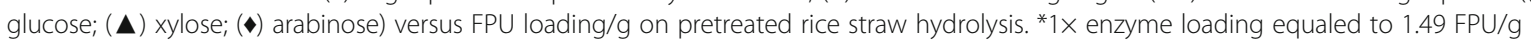

interactions can be explained by several mechanisms [32-34]. Activities of upstream enzymes can be enhanced by cooperative action with downstream enzymes acting on degrading smaller substrates, for example, alleviation of cellobiohydrolase $(\mathrm{CBH})$ inhibition by a $\beta$-D-glucosidase which cleaves cellobiose, the released product with an inhibitory effect to $\mathrm{CBHs}$ to glucose molecules [35]. Synergism can also be resulted from the endo/exo effect between an endoglucanase which creates new, free cellodextrin chain ends for an exo-acting $\mathrm{CBH}$ [36] as well as synergic action between different exoglucanases attacking the reducing and non-reducing ends of cellulose chains [37]. Cooperative action of cellulases and hemicellulases can also increases accessibility to the target substrates of each other, providing synergisms between glycosyl hydrolases attacking different biopolymers in the plant cell wall [38]. Physical modification of the substrates e.g. loosening of the crystalline region of cellulose by auxiliary proteins (e.g. expansins) [32] and non-hydrolytic 
Table 5 Identification of the polysaccharide degrading enzymes in the secretome of Chaetomium globosum BCC5776

\begin{tabular}{|c|c|c|c|c|c|}
\hline \multirow[t]{2}{*}{ Gl number } & $\mathrm{GH}$ & Protein name & Organism & \multirow{2}{*}{$\begin{array}{l}\text { Mascot } \\
\text { Score }\end{array}$} & \multirow{2}{*}{$\begin{array}{l}\text { Prot } \\
\text { Mass }\end{array}$} \\
\hline & \multicolumn{3}{|l|}{ Family } & & \\
\hline 343435330 & $\mathrm{GH} 7$ & Cellobiohydrolase I & Uncultured fungus & 111 & 18482 \\
\hline 343441380 & $\mathrm{GH} 7$ & Cellobiohydrolase I & Uncultured fungus & 60 & 17704 \\
\hline 517325505 & GH5 & Probable cellulase precursor & Fusariam fujikuroi & 59 & 42508 \\
\hline 343435350 & $\mathrm{GH} 7$ & Cellobiohydrolase I & Uncultured fungus & 55 & 18629 \\
\hline 485920895 & GH6 & Putative cellobiohydrolase II protein & Neofusicocum parvum & 167 & 47768 \\
\hline 310801037 & $\mathrm{GH} 7$ & Glycoside hydrolase family 7 endoglucanase & Collectotrichum graminicola & 150 & 49663 \\
\hline 46395332 & $\mathrm{GH7}$ & Cellobiohydrolase & Irpex lacteus & 111 & 56112 \\
\hline 407917740 & GH5 & Glycosyl hydrolase family 5 endoglucanase & Macrophomina phaseolina & 95 & 32163 \\
\hline 477528227 & $\mathrm{GH} 7$ & Exoglucanase type $\mathrm{c}$ precursor & Collectotrichum graminicola & 109 & 52197 \\
\hline 367046256 & $\mathrm{GH7}$ & Glycosyl hydrolase family 7 endoglucanase & Theilavia terrestris & 84 & 56119 \\
\hline 49333363 & $\mathrm{GH} 7$ & Cellobiohydrolase II & Volvariella volvacea & 82 & 55320 \\
\hline 343435720 & $\mathrm{GH} 7$ & Cellobiohydrolase I & Uncultured fungus & 75 & 18463 \\
\hline 575066085 & - & Carbohydrate-binding module family 1 protein & Heterobasidion irregulare & 68 & 35482 \\
\hline 485929653 & - & Putative cellobiose dehydrogenase protein & Neofusicocum parvum & 99 & 897431 \\
\hline 407926573 & GH35 & Glycoside hydrolase family $35 \beta$-galactosidase & Macrophomina phaseolina & 204 & 107902 \\
\hline 407929733 & GH47 & Glycoside hydrolase family 47 a-mannosidase & Macrophomina phaseolina & 122 & 57629 \\
\hline \multirow[t]{2}{*}{74664704} & \multirow[t]{2}{*}{$\mathrm{GH} 10$} & Endo-1,4- $\beta$-xylanase (Xylanase) (EC 3.2.1.8) & \multirow[t]{2}{*}{ Aspergillus oryzae } & \multirow[t]{2}{*}{101} & \multirow[t]{2}{*}{34903} \\
\hline & & (1,4- $\beta-D-x y l a n$ xylanohydrolase) & & & \\
\hline 407926897 & $\mathrm{GH} 10$ & Glycoside hydrolase family 10 endoxylanase & Macrophomina phaseolina & 189 & 34499 \\
\hline 485916263 & $\mathrm{GH} 10$ & Putative endo- $\beta$-xylanase protein & Neofusicocum parvum & 185 & 35125 \\
\hline 485916633 & $\mathrm{GH} 10$ & Putative extracellular endo- $\beta$-protein & Neofusicocum parvum & 130 & 34638 \\
\hline 485919833 & $\mathrm{GH} 11$ & Putative endo- $\beta$-xylanase protein & Neofusicocum parvum & 87 & 23690 \\
\hline 500259512 & $\mathrm{GH} 11$ & Putative endo- $\beta$-xylanase I protein & Phaeoacremonium minimum & 84 & 23642 \\
\hline 485916757 & - & Putative carboxypeptidase s1 protein & Neofusicocum parvum & 78 & 61265 \\
\hline 485919267 & - & Putative leucyl aminopeptidase protein & Neofusicocum parvum & 147 & 40795 \\
\hline 485924582 & - & Putative tripeptidyl-peptidase 1 protein & Neofusicocum parvum & 68 & 65131 \\
\hline 407926489 & - & Polysaccharide deacetylase & Macrophomina phaseolina & 66 & 26890 \\
\hline 325683994 & $\mathrm{GH7}$ & Glycoside hydrolase family 7 endoglucanase & Phialophora sp. & 161 & 50242 \\
\hline
\end{tabular}

enzymes (e.g. lytic polysaccharide monoxygenases) [39] which in overall, results in increased accessibility of the hydrolytic enzymes to the substrates has also been demonstrated. However, they were not annotated in the secretome of C. globosum in this study.

Synergistic enzyme systems are developed by empirically determining combinations of different enzymes for optimal digestibility on specific lignocellulosic substrates in order to reduce enzyme usage without sacrificing the rate or yield from substrate hydrolysis. $T$. reesei cellulase, a well-known cellulase in biomass industry was shown to lack $\beta$-glucosidase activity, resulting in strong inhibition of the cellulase by accumulated cellobiose in the reaction. This inhibition can be overcome by addition of external $\beta$-glucosidase enzymes from different microbial origins [40]. The synergistic action of $T$. reesei cellulase with a crude enzyme mixture from $A$. aculeatus containing various cell wall polysaccharide degrading enzymes with strong downstream cellulolytic and hemicellulolytic activities and a non-catalytic bacterial expansin, acting on physical loosening of the crystalline region of cellulose fibers, on saccharification of alkaline pretreated rice straw was reported [19]. Glycosyl hydrolases from the metagenome of microflora present in sugarcane bagasse can enhance reducing sugar yield of $T$. reesei cellulase [41]. A recent work also showed strong synergistic action of a commercial cellulase, Acellerase 1500 with an endoxylanase, pectate lyase, and a hemicellulose side chain cleaving $\alpha$-arabinofuranosidase [33]. These findings demonstrate the potential of formulating active synergistic enzyme systems from various microbial sources in order to maximize the hydrolysis efficiency on specific lignocellulosic substrates. The glucose releasing efficiency of the 
synergistic ternary enzyme system developed in this study was higher than that reported for Accellerase ${ }^{\circ} 1500$ (81 mg glc/FPU) and the synergistic enzyme systems based on that enzyme, which was in the range of $122-173 \mathrm{mg} / \mathrm{FPU}$ [33]. The efficiency of the ternary enzyme mixture is in the same range to that reported for a synergistic system comprising $T$. reesei cellulase, a crude enzyme from $A$. aculeatus and a bacterial expansin [19] (229 mg glc/FPU) and between $T$. reesei cellulase and enzyme from $A$. awamori [42] (200 mg glc/FPU). The greater efficiency of the C. globosum enzyme system may depend though on the nature of the substrates and hydrolysis conditions. Elucidation of synergized enzyme activities in this study thus provides a basis for further modification of the CG-Cel enzyme either by complementation of lack activities by external in-house enzymes or genetic modification of the strain.

\section{Conclusions}

A biomass-degrading enzyme system from $C$. globosum BCC5776 (CG-Cel), a potent fungus for development of a cellulase producing strain for on-site enzyme production, was characterized. The primary cellulase activity can be augmented by other hydrolytic and nonhydrolytic accessory enzymes. The enzyme system shows a high degree of synergism with commercial $\beta$ glucosidase and hemicellulase. The optimal combination of CG-Cel, $\beta$-glucosidase and hemicellulase was found, leading to marked improvement in the sugar releasing efficiency. The work provides an approach for designing an effective enzyme system with specificity for saccharification of lignocellulosic materials, including agricultural biomass for the biorefinery industry.

\section{Additional files}

Additional file 1: Table S1. Comparison of cellulose production by $C$. globosum BCC5776 and other fungi in recent selected publications. (DOCX $16 \mathrm{~kb})$

Additional file 2: Table S2. Sugar yields from hydrolysis of pretreated rice straw using various enzyme combinations and dosages. (DOCX $15 \mathrm{~kb}$ )

Additional file 3: Figure S1. SDS-PAGE analysis of the BCC5776 crude enzyme extracts. Lane 1- Marker proteins; Lane 2 -the CG-Cel crude enzyme extracts stained with Coomassie brilliant blue. (DOCX $45 \mathrm{~kb}$ )

\section{Abbreviations}

CG-Cel: Cellulase system of Chaetomium globosum BCC5776; CMCase: Cellulase activity on carboxymethyl cellulose; DNS: Dinitrosalicylic acid; EPFB: Empty palm fruit bunch; FPase: Cellulase activity on filter paper; GH: Glycosyl hydrolase; SBM: Soybean meal; TFF: Tangential flow filtration

\section{Acknowledgements}

The authors would like to thank Dr. Philip J. Shaw for manuscript editing.

\section{Funding}

The experimental works including the design of the study and collection, analysis and interpretation of data and manuscript preparation were financially supported by the National Science and Technology Development Agency (Grant number P-15-50502) and The Thailand Research Fund. WW was financially supported by The Petchra Pra Jom Klao Ph.D. Research Scholarship, King Mongkut's University of Technology Thonburi and The Joint Graduate School of Energy and Environment.

\section{Availability of data and materials}

All data are included in the research article and in the Additional files 1,2 and 3.

\section{Authors' contribution}

WW and WS carried out enzyme production, characterization, and mixture design study. NR participated in the upscale fermentation. SS advised on design of experiment. NL and VC contributed to the analysis of the results and manuscript writing. All authors read and approved the final manuscript.

\section{Competing interests}

The authors declare that they have no competing interests.

Consent for publication

Not applicable.

Ethics approval and consent to participate

Not applicable.

\section{Author details}

${ }^{1}$ The Joint Graduate School for Energy and Environment (JGSEE), King Mongkut's University of Technology Thonburi, Prachauthit Road, Bangmod, Bangkok 10140, Thailand. ${ }^{2}$ Enzyme Technology Laboratory, National Center for Genetic Engineering and Biotechnology (BIOTEC), 113 Thailand Science Park, Phahonyothin Road, Khlong Luang, Pathumthani 12120, Thailand. ${ }^{3}$ Bioprocess Laboratory, National Center for Genetic Engineering and Biotechnology (BIOTEC), 113 Thailand Science Park, Phahonyothin Road, Khlong Luang, Pathumthani 12120, Thailand. ${ }^{4}$ BIOTEC-JGSEE Integrative Biorefinery Laboratory, Innovation Cluster 2 Building, 113 Thailand Science Park, Phahonyothin Road, Khlong Luang, Pathumthani 12120, Thailand.

Received: 11 May 2016 Accepted: 1 November 2016

Published online: 21 November 2016

\section{References}

1. Feldman D. Wood_chemistry, ultrastructure, reactions. J Polym Sci. 1985;23:601-2.

2. Ljungdahl LG. The cellulase/hemicellulase system of the anaerobic fungus Orpinomyces PC-2 and aspects of its applied use. Ann N Y Acad Sci. 2008; 1125:308-21.

3. Sánchez C. Lignocellulosic residues: Biodegradation and bioconversion by fungi. Biotechnol Adv. 2009;27:185-94.

4. Howard RL, Abotsi E, van Rensburg EL J, Howard SY. Lignocellulose biotechnology: issue of bioconversion and enzyme production. Afr J Biotechnol. 2003;2:602-19.

5. Woodward J. Enzymatic hydrolysis of cellulose synergism in cellulase systems. Bioresour Technol. 1991;36:67-75.

6. Arantes V, Saddler JN. Access to cellulose limits the efficiency of enzymatic hydrolysis: the role of amorphogenesis. Biotechnol Biofuels. 2010;3:4.

7. Dashtban M, Schraft H, Qin W. Fungal bioconversion of lignocellulosic residues; opportunities \& perspectives. Int J Biol Sci. 2009;5:578-95.

8. Somrithipol S, Hywel-Jones NL, Jones EBG. Seed fungi. In: Jones EBG, Tanticharoen M, Hyde KD, editors. Thai fungal diversity. Thailand: BIOTEC; 2004. p. 129-40

9. El Zayat S-A. Preliminary studies on laccase production by Chaetomium globosum an Endophytic fungus in Glinus lotoides. Am Eurasian J Agric Environ Sci. 2008;3:86-90.

10. Viswanath B, Chandra MS, Pallavi H, Reddy BR. Screening and assessment of laccase producing fungi from different environmental samples. Afr J Biotechnol. 2008;7:1129-33.

11. Abdel-Azeem AM, Gherbawy YA, Sabry AM. Enzyme profiles and genotyping of Chaetomium globosum isolates from various substrates. Plant Biosyst. 2014. doi:10.1080/11263504.2014.984791.

12. Kumar R, Singh $S$, Singh OV. Bioconversion of lignocellulosic biomass: biochemical and molecular perspectives. J Indus Microbiol Biotechnol. 2008;35:377-91. 
13. Sluiter A, Hames B, Ruiz R, Scarlata C, Sluiter J, Templeton D, Crocker D. Determination of structural carbohydrates and lignin in biomass laboratory analytical procedure. Golden: National Renewable Energy Laboratory; 2008.

14. Miller GL. Use of dinitrosalicylic acid reagent for determination of reducing sugar. Anal Chem. 1959;31:426-9.

15. Wood TM, Bhat KM. Methods of measuring cellulase activities. Methods Enzymol. 1988;160:87-117.

16. Wongwilaiwalin S, Rattanachomsri U, Laothanachareon T, Eurwilaichitr L, Igarashi Y, Champreda V. Analysis of a thermophilic lignocellulose degrading microbial consortium and multi-species lignocellulolytic enzyme system. Enzym Microb Technol. 2010;47:283-90.

17. Magrane M, Consortium U. UniProt knowledgebase: a hub of integrated protein data. Oxford: Database; 2011.

18. Cornell J. Experiments with Mixtures: Designs, Models, and the Analysis of Mixture Data. 3rd ed. USA: Wiley; 2002.

19. Suwannarangsee $S$, Bunterngsook B, Arnthong J, Paemanee $A$ Thamchaipenet A, Eurwilaichitr L, Laosiripojana N, Champreda V. Optimisation of synergistic biomass-degrading enzyme systems for efficient rice straw hydrolysis using an experimental mixture design. Bioresour Technol. 2012;119:252-61.

20. Thirumale S, Swaroopa Rani D, Nand K. Control of cellulase formation by trehalose in Clostridium papyrosolvens CFR-703. Proc Biochem. 2001:37:241-5

21. Fang $X$, Yano $S$, Inoue $H$, Sawayama S. Lactose enhances cellulase production by the filamentous fungus Acremonium cellulolyticus. J Biosci Bioeng. 2008;106:115-20.

22. Shiang M, Linden JC, Mohagheghi A, Grohmam K, Himmel ME. Characterization of engF, a gene for a non-cellulosomal Clostridium cellulovoras endoglucanase. Gene. 1991;182:163-7.

23. Li C, Yang Z, He Can Zhang R, Zhang D, Chen S, Ma L. Effect of pH on cellulase production and morphology of Trichoderma reesei and the application in cellulosic material hydrolysis. J Biotechnol. 2013;168:470-7.

24. Prasetyo EN, Kudanga T, Ostergaard L, Rencoret J, Gutierrez A, Rio JCD. Polymerization of lignosulfonates by the laccase-HBT (1hydroxybenzotriazole) system improves dispersibility. Bioresour Technol. 2010;101:5054-62

25. El-Said AHM, Saleem A. Ecological and Physiological Studies on Soil Fungi at Western Region, Libya. Mycobiology. 2008;36:1-9.

26. Golbeck R, Ramos MM, Pereira GAG, Maugeri-Filho F. Cellulase production from a new strain Acremonium strictum isolated from the Brazilian Biome using different substrates. Bioresour Technol. 2013;128:797-803.

27. Kilikian BV, Afonso LC, Souza TFC, Ferreira RG, Pinheiro IR. Filamentous fungi and media for cellulase production in solid state cultures. Braz J Microbiol. 2014:45:279-86

28. Salihu A, Abbas O, Sallau AB, Alam MZ. Agricultural residues for cellulolytic enzyme production by Aspergillus niger: effects of pretreatment. 3. Biotech. 2015:5:1101-6.

29. R Development Core Team. R: A language and environment for statistical computing. Vienna: R Foundation for Statistical Computing; 2008

30. Inoue H, Decker SR, Taylor LE, Yano S, Sawayama S. Identification and characterization of core cellulolytic enzymes from Talaromyces cellulolyticus (formerly Acremonium cellulolyticus) critical for hydrolysis of lignocellulosic biomass. Biotechnol Biofuels. 2014:7:151.

31. Lombard V, Golaconda Ramulu H, Drula E, Coutinho PM, Henrissat B. The carbohydrate-active enzymes database (CAZy) in 2013. Nucleic Acids Res. 2014:42:490-5.

32. Bunterngsook B, Eurwilaichitr L, Thamchaipenet A, Champreda V. Binding characteristics and synergistic effects of bacterial expansins on cellulosic and hemicellulosic substrates. Bioresour Technol. 2015;176:129-35.

33. Laothanachareon L, Bunterngsook B, Suwannarangsee S, Eurwilaichitr L, Champreda V. Synergistic action of recombinant accessory hemicellulolytic and pectinolytic enzymes to Trichoderma reesei cellulase on rice straw degradation. Bioresour Technol. 2015;198:682-90.

34. Leggio LL, Simmons TJ, Poulsen JCN, Frandsen KEH, Hemsworth GR, Stringer MA, Freiesleben PV, Tovborg M, Johansen KS, Maria LD, Harris PV, Soong CL, Dupree P, Tryfona T, Lenfant N, Henrissat B, Davies GJ, Walton $\mathrm{PH}$. Structure and boosting activity of a starch-degrading lytic polysaccharide monooxygenase. Nature Commun. 2015;6:5961. doi:10.1038/ ncomms6961.

35. Horn SJ, Vaaje-Kolstad G, Westereng B, Eijsink VG. Novel enzymes for the degradation of cellulose. Biotechnol Biofuels. 2012;5:45
36. Yang M, Zhang KD, Zhang PY, Zhou X, Ma XQ, Li FL. Synergistic cellulose hydrolysis dominated by a multi-modular processive endoglucanase from Clostridium cellulosi. Front Microbiol. 2016;7:932.

37. Teeri $\Pi$. Crystalline cellulose degradation: new insight into the function of cellobiohydrolases. Trends Biotechnol. 1997;15:160-7.

38. Mohanram S, Amat D, Choudhary J, Arora A, Nain L. Novel perspectives for evolving enzyme cocktails for lignocellulose hydrolysis in biorefineries. Sustain Chem Proc. 2013;1:15.

39. Eibinger M, Ganner T, Bubner P, Rošker S, Kracher D, Haltrich D, Ludwig R, Plank H, Nidetzky B. Cellulose surface degradation by a lytic polysaccharide monooxygenase and its effect on cellulase hydrolytic efficiency. J Biol Chem. 2014;289:35929-38.

40. Dashtban M, Qin W. Overexpression of an exotic thermotolerant $\beta$ glucosidase in Trichoderma reesei and its significant increase in cellulolytic activity and saccharification of barley straw. Microb Cell Fact. 2012;11:1-15.

41. Kanokratana P, Eurwilaichitr L, Pootanakit K, Champreda V. Identification of glycosyl hydrolases from a metagenomic library of microflora in sugarcane bagasse collection site and their cooperative action on cellulose degradation. J Biosci Bioeng. 2015;119:384-91.

42. Gottschalk LMF, Oliveira RA, Bon EPDS. Cellulases, xylanases, $\beta$ glucosidase and ferulic acid esterase produced by Trichoderma and Aspergillus act synergistically in the hydrolysis of sugarcane bagasse. Biochem Eng J. 2010;51:72-8.

\section{Submit your next manuscript to BioMed Central and we will help you at every step:}

- We accept pre-submission inquiries

- Our selector tool helps you to find the most relevant journal

- We provide round the clock customer support

- Convenient online submission

- Thorough peer review

- Inclusion in PubMed and all major indexing services

- Maximum visibility for your research

Submit your manuscript at www.biomedcentral.com/submit
) Biomed Central 